\title{
Annual plankton community metabolism in estuarine and coastal waters in Perth (Western Australia)
}

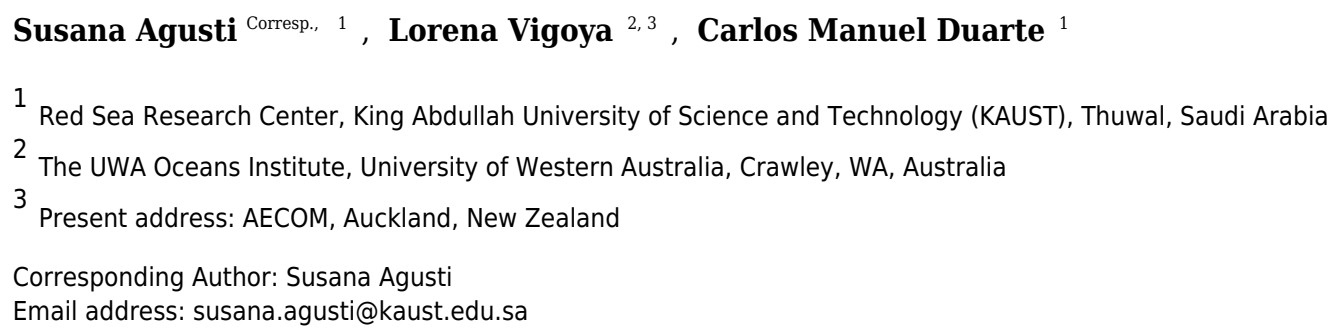

The planktonic metabolic balance that is the balance between gross primary production (GPP) and community respiration (CR) was determined in Matilda Bay (estuarine) and Woodman Point (coastal) in Perth, Western Australia. The rates of net community production (NCP = GPP - CR) and the ratio between GPP and CR (P/R) were assessed to evaluate whether the metabolic balance in the two coastal locations tends to be net autotrophic (production exceeding community respiration) or net heterotrophic (respiration exceeding production). We also analyzed environmental variability by measuring temperature, salinity, and nutrients and chlorophyll a concentration. Samples were collected biweekly from March 2014 to March 2015. During the study period the metabolic rates were three times higher in Matilda Bay than in Woodman Point. The predominant metabolism was net autotrophic at both sites with $\mathrm{P} / \mathrm{R}$ ratios $>1$ in the majority of the sampling dates. In Matilda Bay, the metabolic rates were negatively correlated with salinity denoting river dynamics influence, and positively with chlorophyll a. In Woodman Point only the GPP was positively correlated with chlorophyll $a$. The positive correlation between P/R ratio and GPP in Matilda Bay and the positive correlations between the metabolic rates and chlorophyll a suggest that factors controlling autotrophic processes are modulating the planktonic metabolic balance in the coastal marine ecosystem in Perth. Significant correlations were found between CR and GPP-standardized to chlorophyll $a$ and water temperature. The net autotrophic metabolic balance indicates that in both ecosystems planktonic communities are acting as a sink of $\mathrm{CO}_{2}$ and as a source of organic matter and oxygen to the system and are able to export organic matter to other ecosystems. 


\section{Annual plankton community metabolism in estuarine and coastal}

2 waters in Perth (Western Australia)

3

4 Susana Agusti ${ }^{1}$, Lorena Vigoya ${ }^{2,3}$, and Carlos M. Duarte ${ }^{1}$

5

13 * Corresponding author: Susana Agusti

14 Email address: susana.agusti@,kaust.edu.sa 


\section{Abstract}

18 The planktonic metabolic balance that is the balance between gross primary production (GPP) and community respiration (CR) was determined in Matilda Bay (estuarine) and Woodman Point (coastal) in Perth, Western Australia. The rates of net community production $(\mathrm{NCP}=\mathrm{GPP}-\mathrm{CR})$

21 and the ratio between GPP and CR (P/R) were assessed to evaluate whether the metabolic

22 balance in the two coastal locations tends to be net autotrophic (production exceeding 23 community respiration) or net heterotrophic (respiration exceeding production). We also 24 analyzed environmental variability by measuring temperature, salinity, and nutrients and 25 chlorophyll $a$ concentration. Samples were collected biweekly from March 2014 to March 2015.

26 During the study period the metabolic rates were three times higher in Matilda Bay than in

27 Woodman Point. The predominant metabolism was net autotrophic at both sites with $\mathrm{P} / \mathrm{R}$ ratios $28>1$ in the majority of the sampling dates. In Matilda Bay, the metabolic rates were negatively 29 correlated with salinity denoting river dynamics influence, and positively with chlorophyll $a$. In

30 Woodman Point only the GPP was positively correlated with chlorophyll $a$. The positive 31 correlation between P/R ratio and GPP in Matilda Bay and the positive correlations between the 32 metabolic rates and chlorophyll $a$ suggest that factors controlling autotrophic processes are 33 modulating the planktonic metabolic balance in the coastal marine ecosystem in Perth.

34 Significant correlations were found between CR and GPP standardized to chlorophyll $a$ and 35 water temperature. The net autotrophic metabolic balance indicates that in both ecosystems planktonic communities are acting as a sink of $\mathrm{CO}_{2}$ and as a source of organic matter and oxygen to the system and are able to export organic matter to other ecosystems. 


\section{Introduction}

Plankton metabolism is a fundamental property of marine ecosystem driving the flux of gases and the transference of organic matter to the food web (Duarte et al. 2011). The metabolism of plankton communities in the open ocean is in approximate balance, i.e. with gross primary production (GPP) similar to community respiration $(\mathrm{CR})$ and a $\mathrm{P} / \mathrm{R}$ ratio close to 1.0 , or experiences small deviations from this balance (Williams et al. 2013, Duarte et al. 2013), because deviations from such balance require external fluxes of nutrients or organic carbon, which are small. In contrast, coastal plankton communities, which typically present higher metabolic rates (Duarte and Agustí, 1998), may have large deviations from metabolic balance with either excess respiration over production when the ecosystem receives large inputs of labile organic carbon (e.g. Mediterranean coastal areas, Duarte et al., 2004, Vidussi et al., 2011) or gross primary production in excess of respiration when the ecosystem receives large inputs of dissolved inorganic nutrients (e.g. Agusti et al., 2004).

The metabolic balance of coastal ecosystems plays an important role in determining their role as $\mathrm{CO}_{2}$ sources or sinks (Borges 2005, Cai 2011). Recently, a contrasting role between continental shelves acting as sinks and near-shore ecosystems as sources of atmospheric $\mathrm{CO}_{2}$ was proposed to reconcile opposing views on the role of coastal ecosystems as $\mathrm{CO}_{2}$ sources or sinks (Chen and Borges, 2009; Cai, 2011). In particular, inner estuaries are believed to act as sources of $\mathrm{CO}_{2}$ to the atmosphere due to a prevalence of heterotrophic ecosystem metabolic status fueled by landderived inputs of organic carbon whereas outer reaches of estuaries tend to be $\mathrm{CO}_{2}$ sinks (Odum and Hoskin, 1958; Odum and Wilson, 1962; Heip et al., 1995; Kemp et al., 1997; Gattuso et al., 1998; Hopkinson and Smith, 2005).

However, virtually all of the results from near-shore and open coastal ecosystems thus far refer to those in the northern hemisphere, particularly Europe, the USA and Asia (Borges, 2005; Chen and Borges, 2009; Cai, 2011). As these typically represent highly populated areas with watersheds supporting intense agricultural practices, the results may not be directly transferable to coastal areas in the southern hemisphere. The metabolism of Australian coastal waters was recently studied by McKinnon et al. (2013) and (2017). Autotrophic plankton metabolism 
70 prevailed in the coastal zone of the Great Barrier Reef (GBR) (McKinnon et al., 2013), despite

71 being located in the wet Australian tropics with a distinct rainy season. Moreover, the inshore

72 area was even more strongly autotrophic than the offshore region of the GBR, which is in

73 contrast to the expectation that inshore coastal waters should be heterotrophic. Coastal waters

74 adjacent to Northern Australia were also predominantly autotrophic (McKinnon et al. 2017).

75 Whether autotrophic metabolism could prevalent in other regions of Australia is, thus far,

76 unresolved.

77

78

Here we report plankton metabolic rates for two contrasting coastal sites in the Perth area in temperate Western Australia, Matilda Bay, an inshore-site in the Swan river estuary, and Woodsman Point, an open coastal site. Specifically, we assessed biweekly during a year (March 2014 to March 2015) community respiration,, gross primary production and net community

82 production, along with temperature, salinity, dissolved inorganic nutrient concentration, and 83 chlorophyll $a$ concentration.

\section{Methods}

Matilda Bay is located in the lower reaches of the Swan River. Swan is one of the main rivers in Western Australia with an extension of more than $50 \mathrm{~km}$ and a catchment area about 190,000 $\mathrm{Km}^{2}$ (Thomson, 1998). The estuary has been open to the ocean since 1987 when a rocky bar near to the mouth of the estuary in Fremantle was removed. The estuary has a seasonal cycle influenced by rainfall with wet and cool winters with about $90 \%$ of the annual rain and hot and dry summers (Thomson, 1998; Hamilton et al., 2006). During winter most of the water body is fresh because of the rainfall and runoff but the salinity increases upstream when the rainfall decreases and the system receive a significant flow of oceanic waters (Thompson 1998). The estuary has received anthropogenic pressure because of land clearing for agricultural purposes, urbanization, dam construction and other factors (Chan et al. 2002; Thompson 1998).

97 Consequently, nutrient inputs and sedimentation rates have increased and the water quality has decreased (Chan et al. 2002; Hamilton et al. 2006). Gedaria (2012) reported that salinity and temperature are the main drivers of the variation in phytoplankton biomass in the Swan River 
101 (Perth, Western Australia), and, in contrast with Matilda Bay, represents an open shoreline with

102 no direct freshwater influence. Cockburn. Sound area was a place of industrial activity reducing 103 coastal water quality in the 1950s due to phytoplankton blooms (Cambridge \& McComb 1984).

104 However, the water quality has improved since the mid-1990s due to the reduction of nutrients

105 inputs from industrial activities (Kendrick et al. 2002). The coastal area of Western Australia is 106 also influenced by the Leeuwin Current, a poleward-flowing eastern boundary current

107 characterized by warm waters with low salinity and low nutrients, but weakening between

108 November and March (Cresswell \& Golding 1980).

109

110 Sub-surface water samples were collected at biweekly intervals between March 2014 to March

1112015 in Matilda Bay (-31.9904 ${ }^{\circ} \mathrm{S}, 115.8181^{\circ} \mathrm{E}$; Fig. 1) and the Ammunition Jetty, Woodman

112 Point (-32.1241 ㅇ, $115.7586^{\circ} \mathrm{E}$; Fig. 1). The free software Ocean Data View (Schlitzer, R.,

113 Ocean Data View, http://odv.awi.de, 2016), version 4.7.10, was used to generate the study area

114 map. Samples were then transported to incubated and processed at the University of Western

115 Australia (UWA). Temperature $\left({ }^{\circ} \mathrm{C}\right)$, Salinity and dissolved oxygen were measured through the

116 water column by deploying a calibrated YSI EXO1 Multi-parameter Water Quality Sonde fitted

117 with a pressure sensor $( \pm 0.04 \mathrm{~m})$, temperature $\left( \pm 0.01^{\circ} \mathrm{C}\right)$, conductivity sensor, and an optode

118 dissolved oxygen sensor. In addition, surface water temperature was measured from the water

119 collected by a digital thermometer.

120

121 Net community production, gross primary production, and community respiration were

122 quantified by changes in dissolved oxygen using micro-Winkler techniques by the use of a

123 precise automatic titration based on redox potentiometric endpoint (Oudot et al., 1988). Water

124 collected in each site was siphoned into 21 calibrated glass $100 \mathrm{ml}$ borosilicate Winkler bottles.

125 Seven bottles were fixed immediately to measure initial oxygen, another seven bottles were

126 incubated in the light and the last seven bottles were incubated in the dark. The incubation,

127 starting between 8 to 9 am, was run for 24 hours in situ conditions of temperature and natural

128 solar radiation in an outdoor, temperature controlled tank. After the incubation, samples were

129 fixed and the final oxygen was measured using a high-precision autotitrator (Compact Titrator

130 G20, Mettler Toledo). NCP rates were determined from the oxygen change in the clear bottles

131 (oxygen clear - initial oxygen), CR rates were determined from the oxygen change in the dark 
132 bottles (Initial oxygen - dark oxygen) and GPP rates were calculated as the sum of CR and NCP

133 (Duarte et al., 2011). Model II regression was used to analyse the relationships between CR,

134 NCP, and GPP.

135

136 Aliquots of $200 \mathrm{ml}$ were used for chlorophyll $a$ analyses using acetone extraction and

137 fluorometric determination after Parsons et al. (1984). Subsamples were filtered through

138 Whatman grade GF/F glass microfiber filters of $25 \mathrm{~mm}$ diameter. Filters were placed in plastic

139 tubes of $1 \mathrm{ml}$ and stored at $-20^{\circ} \mathrm{C}$ until analysis. Filters were immersed in acetone at $90 \%$ during

14024 hours for chlorophyll $a$ extraction. After that period, chlorophyll $a$ fluorescence was measured

141 by the use of a Trilogy Laboratory Fluorometer (Turner Designs) equipped with a module of

142 Chlorophyll a Non-Acidification Fluorescent Module (CHL-A NA) at UWA. The fluorometer

143 was calibrated with pure chlorophyll a (Sigma- Aldrich C6144-1mg) solution.

144

145 Samples for dissolved inorganic nutrient analyses were collected during transportation to the

146 laboratory and kept frozen until analysis in a segmented flow autoanalyzer following standard

147 procedures Samples (Hansen and Koroleff, 1999).

148

149 The temperature response of plankton communities was described by fitting, using least squares

150 regression analysis, the Arrhenius equation,

151

152

$$
\operatorname{Ln} \mathrm{Y}=\mathrm{A} \exp ^{-\mathrm{AE} / \mathrm{kT}}
$$

153

154 where $\mathrm{Y}$ is the property of interest, $\mathrm{AE}$ is the activation energy $(\mathrm{eV}), \mathrm{k}$ is the

155 Boltzmann' s constant $\left(8.61773410-5 \mathrm{eV}^{\circ} \mathrm{K}^{-1}\right)$ and $\mathrm{T}$ is the sea-surface water temperature $\left({ }^{\circ} \mathrm{K}\right)$,

156 and $\mathrm{A}$ is a fitted intercept (Regaudie-de-Gioux and Duarte, 2012).

157

158

159

Results

160

161 Surface water temperature ranged from 12.0 to $27.4^{\circ} \mathrm{C}$ and 15.1 to $25.0^{\circ} \mathrm{C}$ (Fig. 2a) and salinity 162 ranged from 22.03 to 36.97 PSU and 31.6 to 37.1 PSU (Fig. 2b) in Matilda Bay and Woodman 
163 Point, respectively. The minimum salinity was reached in late winter and spring in Matilda Bay,

164 following river discharge, and while the pattern was less clear in Woodman Point, the lowest

165 salinity was also observed in winter and early spring (Fig. 2b). Dissolved inorganic nitrogen

166 concentration was highest in winter, but phosphate concentration was highest in late summer in

167 Matilda Bay (Fig. 3a-c). In contrast, nitrate and phosphate concentrations in Woodman Point

168 were lower $(\mathrm{P}<0.05)$ than those in Matilda Bay (Table 1) and dissolved inorganic nitrogen

169 concentration showed two maxima, winter and summer, while phosphate concentrations showed

170 a summer minima (Fig. 3a-c). Chlorophyll $a$ concentration was significantly higher and more

171 variable in Matilda Bay than in Woodman Point (Table 1, Fig. 3d), and reached the highest

172 values in winter, at the time of peak nitrate concentration (Fig. 3d), as there was a significant,

173 positive, relationship between chlorophyll $a$ concentration and nitrate concentration $(\mathrm{r}=0.67, \mathrm{P}$

$174<0.0001)$.

175

176 Respiration rates were, on average, twice as high in Matilda Bay as in Woodman Point (Table 1),

177 and increased strongly toward summer in Woodman Point whereas it showed less seasonal

178 variability in Matilda Bay (Fig. 4a). Gross primary production was also much higher in Matilda

179 Bay than in Woodman Point (Table 1), with no clear seasonal pattern at either site (Fig. 4b). The

180 communities were generally autotrophic, with GPP about twice as high as R (NCP and P/R > 1,

181 Table 1), with NCP being three times higher, on average, at Matilda Bay than at Woodman Point

182 (Table 1, Fig. 4c), and neither community displayed any clear seasonal trend in net community

183 production along the year (Fig. 4c). GPP was significantly correlated with $\mathrm{CR}(\mathrm{r}=0.68, \mathrm{P}<$

184 0.0001), but NCP increased strongly with increasing GPP (Fig. 5). Net community production

185 and gross primary production increased with increasing chlorophyll $a$ concentration $\left(\mathrm{NCP}, \mathrm{R}^{2}=\right.$

$\left.1860.73, \mathrm{P}<0.0001 ; \mathrm{GPP}, \mathrm{R}^{2}=0.69, \mathrm{P}<0.0001\right)$, with the relationship between community

187 respiration rate and chlorophyll $a$ being much weaker $\left(C R, \mathrm{R}^{2}=0.15, \mathrm{P}=0.0036\right)$ albeit also

188 significant (Fig. 6 a, b, c).

189

190 Respiration rates increased with increasing temperature, resulting in an activation energy of 0.76

$191 \pm 0.21 \mathrm{eV}$ (Fig. 7a). GPP showed, in contrast, no significant temperature-dependence $(\mathrm{P}>0.05)$.

192 Indeed, when standardized to chlorophyll $a$, as observed in previous studies (e.g. Regaudie de-

193 Gioux and Duarte, 2012; Garcia-Corral et al., 2017), there was a significant temperature- 
194 dependence of gross primary production, with an activation energy of $0.69 \pm 0.12$ (Fig. 7b),

195 comparable to that of community respiration.

196

\section{Discussion}

198

199

Chlorophyll $a$ values were higher in Matilda Bay than in Woodman point, but all values ranged within those reported for coastal waters around Perth (Pearce et al., 2006). The highest

201 chlorophyll $a$ concentration in both Matilda Bay and Woodman point occurred at the low salinity winter events. Chlorophyll $a$ concentration in the Swan River has been reported to vary seasonally showing large interannual variability (Thompson, 1998). Both coastal ecosystems, but particularly Matilda Bay, supported productive communities, as reflected in high GPP rates.

Community respiration rates were less variable than GPP, particularly at Matilda Bay, but GPP sufficed to support all carbon demands from the community generating excess organic matter. This resulted in the prevalence of autotrophic communities at both sites, with average P/R ratios above 2.0 similar across both sites. This is expected from relatively productive sites with GPP well above the threshold previously determined to delineate autotrophic from heterotrophic communities (Duarte \& Agustí, 1998; Duarte \& Regaudie-de-Gioux, 2009). Net community production was strongly correlated with chlorophyll $a$ concentration, accounting for the much

213 higher NCP in productive Matilda Bay compared to Woodman Point plankton communities,

214 suggesting that the metabolic balance of plankton communities in the coast of Perth is regulated

215 by factors controlling autotrophic processes, such as nutrient inputs, salinity regimes and

216 temperature. In coastal waters of Northern Australia, McKinnon et al (2017) also observed that

217 the metabolism and community respiration were autotrophic and positively related to chlorophyll $218 a$ concentration.

220 The results presented here contribute to address a paucity of studies of plankton community 221 metabolism in the Indian Ocean (Regaudie-de-Gioux \& Duarte, 2013). Robinson and Williams 222 (1999) studied the planktonic metabolic balance during a research cruise in the Gulf of Oman, 223 reporting $\mathrm{P} / \mathrm{R}$ ratios for surface waters between 1.17 and 2.43 , with the highest ratio near to the 224 Omani coast (Regaudie-de-Gioux \& Duarte, 2013; Robinson \& Williams, 1999). Indeed, the P/R 
225 ratio of the station closer to the Omani coast, 2.43 (Robinson \& Williams, 1999) was similar to 226 the P/R ratio for out study sites in the Western Australia coast. More recently, Mackinnon et al. 227 (2017) in a comprehensive study of the metabolism of planktonic communities in the North of 228 Australia, found that Indian Ocean communities from Ningaloo Reef and Exmouth Gulf (North 229 Western Australia coast) were also predominantly net autotrophic.

230

231 Our results indeed showed a prevalence of net autotrophic metabolism in plankton communities 232 of the Coast of Perth (Western Australia), both at the productive estuarine waters at Matilda Bay 233 and the open coastal Indian Ocean waters at Woodman Point. This indicates that planktonic 234 communities in these coastal locations act as strong $\mathrm{CO}_{2}$ sinks and sources of organic matter and 235 oxygen to the system. This is in contrast to the expectation that near-shore ecosystems act as 236 sources of atmospheric $\mathrm{CO}_{2}$, proposed to reconcile opposing views on the role of coastal 237 ecosystems as $\mathrm{CO}_{2}$ sources or sinks (Chen \& Borges, 2009; Cai, 2011). Indeed, the pattern 238 showed here, with higher net community production in the inner waters of Matilda Bay 239 compared to the more open waters at Woodman Point agree with prior findings for Australian 240 GBR where inshore areas being more strongly autotrophic than offshore waters (McKinnon et 241 al., 2013).

243 The plankton communities in the coastal waters of Perth showed increased metabolic rates with 244 increasing temperature, as expected from metabolic theory of ecology (Brown et al., 2004).

245 However, the activation energy for gross primary production of $0.69 \pm 0.12 \mathrm{eV}$ found here was 246 well below that found in previous analyses of Indian Ocean communities. Garcia-Corral et al.

247 (2017) reported for Indian Ocean open-ocean waters a gross primary production Ea (standardized 248 to chlorophyll $a$ ) of $1.70 \mathrm{eV}$. Also, whereas, consistent with other assessments (e.g. Regaudie de-

249 Gioux \& Duarte 2012; Garcia-Corral et al., 2017), the activation energy for community

250 respiration was higher than that for gross primary production, this difference was small and not 251 statistically significant. This is important as it predicts that warming events, such as the heat 252 wave that impacted marine ecosystems across Western Australia in 2011 (Wernberg et al., 2016), 253 will affect gross primary production and respiration rates of plankton communities in a similar 254 way. 
256 The net autotrophic communities encountered in the coastal system studied in Western Australia

257 suggest that these pelagic communities produce organic matter in excess, thereby exporting

258 organic matter either to the underlying benthic compartment or offshore. For instance, analysis

259 of carbon stocks in Matilda Bay sediments, which support seagrass meadows, have shown the

260 organic carbon to be partially of planktonic origin along with contributions of the seagrass

261 themselves (Rozaimi et al. 2013). Hence, both the pelagic and benthic compartments of Matilda

262 Bay appear to be autotrophic, although the contributions of the benthic compartment to

263 ecosystem metabolism were not addressed here. We, therefore, provide only one of the

264 components, pelagic metabolism, that determine ecosystem metabolic budgets, which include

265 contributions from benthic compartments as well as exchanges, either import or export, with

266 adjacent ecosystems.

267

268 Conclusions

269

270 Our results indicated that planktonic communities in the two coastal Western Australia locations

271 studied act as strong $\mathrm{CO}_{2}$ sinks and sources of organic matter and oxygen to the system. The

272 plankton communities of the Coast of Perth (Western Australia) showed net autotrophic

273 metabolism both at the productive estuarine waters at Matilda Bay and the open coastal Indian

274 Ocean waters at Woodman Point. This result is in contrast to the expectation of net

275 heterotrophic balance for near-shore ecosystems, but in agreement with the few metabolic

276 balance assessments from Australian coastal waters. The thermal relationships indicated that

277 warming may decrease the strong capacity observed for $\mathrm{CO}_{2}$ sinks. Our study is based on two

278 contrasting plankton communities in Western Australia and, while useful to address the absence

279 of reports on plankton community metabolism in the Indian Ocean coast of Australia, and the

280 paucity of reports across the Indian Ocean (Regaudie de-Gioux \& Duarte 2013), a broader

281 analyses of coastal plankton communities across Western Australia is required to confirm the

282 patterns revealed here and diagnose the role of plankton communities in across Western

283 Australia in carbon fluxes and their likely response to future warming.

284

285

286 


\section{Acknowledgement}

290 We thank Lara García Corral and María Comesaña for their assistance with sampling and

291 analyses.

\section{References}

297

298

299

300

301

302

303

304

Agustí S, Satta MP, Mura MP. 2004. Summer community respiration and pelagic metabolism in surface Antarctic waters. Aquatic Microbial Ecology 35: 197-205.

Borges AV. 2005. Do we have enough pieces of the jigsaw to integrate $\mathrm{CO}_{2}$ fluxes in the coastal ocean? Estuaries 28:3-27.

Brown JH, Gillooly JF, Allen AP, Savage VM, West GB. 2004. Toward a metabolic theory of ecology 85:1771-1789.

Cai W-J. 2011. Estuarine and coastal ocean carbon paradox: $\mathrm{CO}_{2}$ sinks or sites of terrestrial carbon incineration? Annual Review of Marine Science 3:123-145.

Cambridge, M L, McComb, A J (1984). The loss of seagrasses in Cockburn Sound, Western Australia. I. The time course and magnitude of seagrass decline in relation to industrial development. Aquatic Botany, 20(3-4), 229-243

309 Chan TU, Hamilton DP, Robson BJ, Hodges BR, Dallimore C. 2002. Impacts of Hydrological Changes on Phytoplankton Succession in the Swan River, Western Australia.Estuaries 25:1406-1415.

312

Chen CTArthur, Borges AV. 2009. Reconciling opposing views on carbon cycling in the coastal ocean: Continental shelves as sinks and near-shore ecosystems as sources of atmospheric CO2. Deep Sea Research Part II: Topical Studies in Oceanography 56: 578-590.

315 Cresswell GR, Golding TJ. 1980. Observations of a south-flowing current in the southeastern Indian Ocean. Deep Sea Research Part A. Oceanographic Research Papers 27: 449-466. 
317 Duarte CM, Agustí S. 1998. The $\mathrm{CO}_{2}$ balance of unproductive aquatic ecosystems. Science $318 \quad 281: 234-236$.

319 Duarte CM,Agustí S, Vaqué D. 2004. Controls on Planktonic Metabolism in the Bay of Blanes, Northwestern Mediterranean Littoral. Limnology and Oceanography 49: 2162-2170.

321

322

323

324

325

326

327

328

329

330

331

332

333

334

335

336

337

338

339

340

341

342

343

344

345

346

347

348

349

350

351

352

Duarte CM, Agustí S, Regaudie-de-GiouxA. 2011. The role of marine biota in the metabolism of the biosphere. In: Duarte CM, ed. The role of marine biota in the functioning of the biosphere. Spain: Fundacion BBVA, 39-53.

Duarte CM, Regaudie-de-Gioux A. 2009. Thresholds of gross primary production for the metabolic balance of marine planktonic communities. Limnology and Oceanography 54:1015-1022.

Duarte CM, A. Regaudie-de-Gioux, Arrieta JM, Delgado-Huertas A, Agustí S. 2013. The Oligotrophic Ocean Is Heterotrophic. Annual Review of Marine Science 5: 551-569.

Garcia-Corral LS, Holding JM, Carrillo-de-Albornoz P, Steckbauer A, Pérez-Lorenzo M, Navarro N, Serret P, Gasol JM, Morán XAG, Estrada M, Fraile-Nuez E, Benítez-Barrios V, Agustí S, Duarte CM. 2017. Temperature dependence of plankton community metabolism in the subtropical and tropical ocean. Global Biogeochemical Cycles 31: 1141-1154.

Gattuso, JP, Frankignoulle M, Wollast R. 1998. Carbon and carbonate metabolism in coastal aquatic ecosystems. Annual Review of Ecology and Systematics 29:405-434.

Gedaria AI. 2012. Niche partitioning of Microbial Populations in the Swan - Canning Estuary. Doctoral Thesis, The University of Western Australia.

Hamilton DP, Douglas GB, Adeney JA, Radke LC. 2006. Seasonal changes in major ions, nutrients and chlorophyll $a$ at two sites in the Swan River estuary, Western Australia. Marine and Freshwater Research 57(8): 803-815.

Hansen HP, Koroleff F. 1999. Determination of nutrients. In: Grasshoff K, Kremling K, Ehrhardt $\mathrm{M}$, ed. Methods of seawater analysis, $3^{\text {rd }}$ edn. Germany: Wiley-VCH Verlag GmbH, 159228.

Heip CHR, Goosen NK, Herman PMJ, Kromkamp JC, Middelburg JJ, Soetaert KER. 1995. Production and consumption of biological particles in temperate tidal estuaries. Oceanography and Marine Biology: an annual review 33:1-149

Hopkinson CSJ, Smith EM. 2005. Estuarine respiration: An overview of benthic, pelagic and whole system respiration, In: Giorgio PA, Williams PJL, ed. Respiration in Aquatic Ecosystems. New York: Oxford University Press, 122-146.

Kemp WM, Smith EM, Marvin-DiPasquale M, Boynton WR. 1997. Organic carbon balance and net ecosystem metabolism in Chesapeake Bay. Marine Ecology Progress Series 150:229-248. 
353 Kendrick, G A, Aylward, M J, Hegge, B J, Cambridge, M L, Hillman, K, Wyllie, A, Lord, D A.

354

355

356

357

358

359

360

361

362

363

364

365

366

367

368

369

370

371

372

373

374

375

376

377

378

379

380

381

382

383

384

385

386

387
2002. Changes in seagrass coverage in Cockburn Sound, Western Australia between 1967 and 1999. Aquatic Botany, 73: 75-87.

McKinnon AD, Logan M, Castine, SA, Duggan, S. 2013. Pelagic metabolism in the waters of the Great Barrier Reef. Limnology and Oceanography 58: 1227-1242.

McKinnon AD, Duggan S, Logan M, Lønborg C. 2017. Plankton Respiration, Production, and trophic state in tropical coastal and shelf waters adjacent to northern Australia. Front. Mar. Sci. 4:346. doi: 10.3389/fmars.2017.00346

Odum HT, Wilson R. 1962. Further studies on the reaeration and metabolism of Texas bays, , 1958-1960. Institute of Marine Science Publications 8:23-55.

Odum HT, Hoskin CM. 1958. Comparative studies of the metabolism of Texas bays. Institute of Marine Science Publications 5:16-46.

Oudot C, Gerard R, Morin P, Gningue, I. 1988. Precise shipboard determination of dissolved oxygen (Winkler procedure) for productivity studies with a commercial system. Limnology and Oceanography, 33: 146-150.

Parsons TR, Maita Y, Lalli CM. 1984. A Manual of Chemical and Biological Methods for Seawater Analysis. Oxford: Pergamon Press.

Pearce AF, Lynch MJ, Hanson CE. 2006. The Hillarys Transect (1): Seasonal and cross-shelf variability of physical and chemical water properties off Perth, Western Australia, 199698. Continental Shelf Research 26:1689-1729.

Regaudie-de-Gioux A, Duarte CM. 2012. Temperature dependence of planktonic metabolism in the ocean. Global Biogeochemical Cycles 26:GB1015.

Regaudie-de-Gioux A, Duarte CM. 2013. Global patterns in oceanic planktonic metabolism. Journal Limnology and Oceanography 58(3):977-985.

Robinson C, Williams PJB. 1999. Plankton net community production and dark respiration in the Arabian Sea during September 1994. Deep Sea Research Part II: Topical Studies in Oceanography 46:745-765.

Rozaimi M, Serrano O, Lavery, PS. 2013. Comparison of carbon stores by two morphologically different seagrasses. Journal of the Royal Society of Western Australia 96,: 81-83.

Thompson PA. 1998. Spatial and Temporal Patterns of Factors Influencing Phytoplankton in a Salt Wedge Estuary, the Swan River, Western Australia. Estuaries 21(4):801-817.

Vidussi F, Mostajir B,Fouilland E,Floc'h EL,Nouguier J, Roques C, Got P,Thibault-Botha D, Bouvier T, Troussellier M. 2011. Effects of experimental warming and increased ultraviolet B radiation on the Mediterranean plankton food web. Limnology and Oceanography 56: 206-218. 
388 Wernberg T, Bennett S, Babcock RC, de Bettignies T, Cure K, Depczynski M, Dufois F, Fromont J, Fulton CJ, Hovey RK, Harvey ES, Holmes TH, Kendrick GA, Radford B, Santana-Garcon J, Saunders BJ, Smale DA, Thomsen MS, Tuckett CA, Tuya F, Vanderklift MA, Wilson S. 2016. Climate-driven regime shift of a temperate marine ecosystem. Science 353(6295):169-172.

395

396

397

Williams PJLB, Quay PD, Westberry TK, Behrenfeld MJ. 2013. The oligotrophic ocean is autotrophic. Annual Review of Marine Science 5, 535-549. 
398

399

400

401

402

403

404

405

406

407

408

409

410

411

412

413

414

415

416

417

418

419

420

421

422

423

424

425

426

427

\section{Figure Headings}

Figure 1: Map showing the study area in Western Australia. The stations sampled in the coast of Perth are marked with green (Matilda Bay) and red (Woodman Point) dots.

Figure 2: Temporal variability in seawater temperature and salinity. Changes in surface seawater temperature (A) and salinity (B) in Matilda Bay are shown in blue line and symbols, and in Woodman Point in red line and symbols, over time.

Figure 3: Nutrients and chlorophyll $\boldsymbol{a}$ variability. Changes in (A) nitrate, (B) ammonium, (C) phosphate and (D) chlorophyll $a$ concentration in Matilda Bay (blue line and symbols) and Woodman Point (red line and symbols) over time.

Figure 4: Planktonic metabolism. Changes in (A) community respiration rate, (B) gross primary production, and (C) net community production in Matilda Bay (blue line and symbols) and Woodman Point (red line and symbols) over time.

Figure 5. The relationship between net community production and gross primary production. The solid line shows the fitted regression equation: $\mathrm{NCP}\left(\mathrm{mmol} \mathrm{O}_{2} \mathrm{~m}^{-3} \mathrm{~d}^{-1}\right)=-2.65$ $+0.65( \pm 0.05)$ GPP $\left(\mathrm{mmol} \mathrm{O}_{2} \mathrm{~m}^{-3} \mathrm{~d}^{-1}\right)\left(\mathrm{R}^{2}=0.75, \mathrm{P}<0.0001\right)$. Blue symbols and red symbols correspond to Matilda Bay and Woodman Point, respectively.

Figure 6. Plankton metabolism and phytoplankton. The relationship between (A) net community production, (B) gross primary production and (C) community respiration and chlorophyll $a$ concentration. The solid lines show the fitted regression equations: (A) NCP $\left(\mathrm{mmol} \mathrm{O}_{2} \mathrm{~m}^{-3} \mathrm{~d}^{-1}\right)=-1.54+2.29( \pm 0.19) \mathrm{Chl} a\left(\mu \mathrm{g} \mathrm{Chl} a \mathrm{~L}^{-1}\right)\left(\mathrm{R}^{2}=0.73, \mathrm{P}<0.0001\right) ;(\mathrm{B})$ GPP $\left(\mathrm{mmol} \mathrm{O}_{2} \mathrm{~m}^{-3} \mathrm{~d}^{-1}\right)=2.93+3.03( \pm 0.05) \mathrm{Chl} a\left(\mu \mathrm{g} \mathrm{Chl} a \mathrm{~L}^{-1}\right)\left(\mathrm{R}^{2}=0.69, \mathrm{P}<0.0001\right) ;$ and $(\mathrm{C}) \mathrm{R}$ $\left(\mathrm{mmol} \mathrm{O}_{2} \mathrm{~m}^{-3} \mathrm{~d}^{-1}\right)=4.45+0.74( \pm 0.24) \mathrm{Chl} a\left(\mu \mathrm{g} \mathrm{Chl} a \mathrm{~L}^{-1}\right)\left(\mathrm{R}^{2}=0.15, \mathrm{P}=0.0036\right)$. Blue symbols and red symbols correspond to Matilda Bay and Woodman Point, respectively. 
428 Figure 7: Thermal relationships. Arrhenius plots showing the relationship between the natural $429 \log$ of (A) community respiration and (B) gross primary production standardized to chlorophyll $430 a$, and $1 / \mathrm{kT}$, where $\mathrm{k}$ is the Boltzmann' s constant $\left(8.61773410-5 \mathrm{eV}^{\circ} \mathrm{K}^{-1}\right)$ and $\mathrm{T}$ is the sea431 surface water temperature $\left({ }^{\circ} \mathrm{K}\right)$ in Matilda Bay (blue symbols) and Woodman Point (red 432 symbols). The solid lines show the fitted equations: $\ln \mathrm{R}\left(\mathrm{mmol} \mathrm{O}_{2} \mathrm{mg} \mathrm{m}^{-3} \mathrm{~d}^{-1}\right)=31.87-0.76( \pm$ $4330.21) 1 / \mathrm{kT}\left(\mathrm{R}^{2}=0.21, \mathrm{P}=0.0008\right)$ and $\ln \mathrm{GPP} / \mathrm{Chl} \mathrm{a}\left(\mathrm{mmol} \mathrm{O}_{2} \mathrm{mg} \mathrm{Chl} a^{-1} \mathrm{~d}^{-1}\right)=28.8-0.69( \pm$ $4340.12) 1 / k T\left(\mathrm{R}^{2}=0.41, \mathrm{P}<0.0001\right)$. 


\section{Table $\mathbf{1}$ (on next page)}

Mean $( \pm \mathrm{SE})$ of the variables measured in Matilda Bay and Woodman Point (Western Australia).

$\mathrm{NCP}=$ net community production, $\mathrm{GPP}=$ gross primary production and $\mathrm{P} / \mathrm{R}=$ is the ratio of GPP over R. Asterisks denotes statistically significant difference (t-test, $\mathrm{P}<0.05$ ). 
1

\begin{tabular}{lrcrc}
\hline & \multicolumn{2}{c}{ Matilda Bay } & \multicolumn{2}{c}{ Woodman Point } \\
& Mean & $\pm \mathrm{SE}(\mathrm{N}=33)$ & Mean & $\pm \mathrm{SE}(\mathrm{N}=27)$ \\
\hline Temperature $\left({ }^{\circ} \mathrm{C}\right)$ & 20.90 & 0.66 & 20.79 & 0.57 \\
Salinity & 32.09 & 0.95 & $35.13^{*}$ & 0.29 \\
Ammonia $\left(\mu \mathrm{mol} \mathrm{N} \mathrm{L}^{-1}\right)$ & 2.68 & 0.30 & 2.17 & 0.29 \\
Nitrate $(\mu \mathrm{mol} \mathrm{N} \mathrm{L}-1)$ & 2.32 & 0.71 & $0.56^{*}$ & 0.08 \\
Phosphate $\left(\mu \mathrm{mol} \mathrm{P} \mathrm{L}^{-1}\right)$ & 0.52 & 0.06 & $0.20^{*}$ & 0.02 \\
Chlorophyll a $\left(\mu{\left.\mathrm{g} \mathrm{Chl} a \mathrm{~L}^{-1}\right)}\right)$ & 4.05 & 0.47 & $1.68^{*}$ & 0.14 \\
Respiration $\left(\mu \mathrm{mol} \mathrm{O}_{2} \mathrm{~L}^{-1} \mathrm{~d}^{-1}\right)$ & 8.81 & 0.76 & $4.33^{*}$ & 0.48 \\
NCP $\left(\mu \mathrm{mol} \mathrm{O} \mathrm{L}^{-1} \mathrm{~d}^{-1}\right)$ & 7.21 & 1.29 & $2.32^{*}$ & 0.61 \\
$\mathrm{GPP}\left(\mu \mathrm{mol} \mathrm{O}_{2} \mathrm{~d}^{-1}\right)$ & 16.05 & 1.56 & $6.23 *$ & 0.60 \\
$\mathrm{P} / \mathrm{R}$ & 1.91 & 0.14 & 2.05 & 0.27 \\
\hline
\end{tabular}

2

3 


\section{Figure 1}

Map showing the study area in Western Australia.

The stations sampled in the coast of Perth are marked with green (Matilda Bay) and red (Woodman Point) dots. The free software Ocean Data View (Schlitzer, R., Ocean Data View, http://odv.awi.de, 2016), version 4.7.10, was used to generate the study area map.

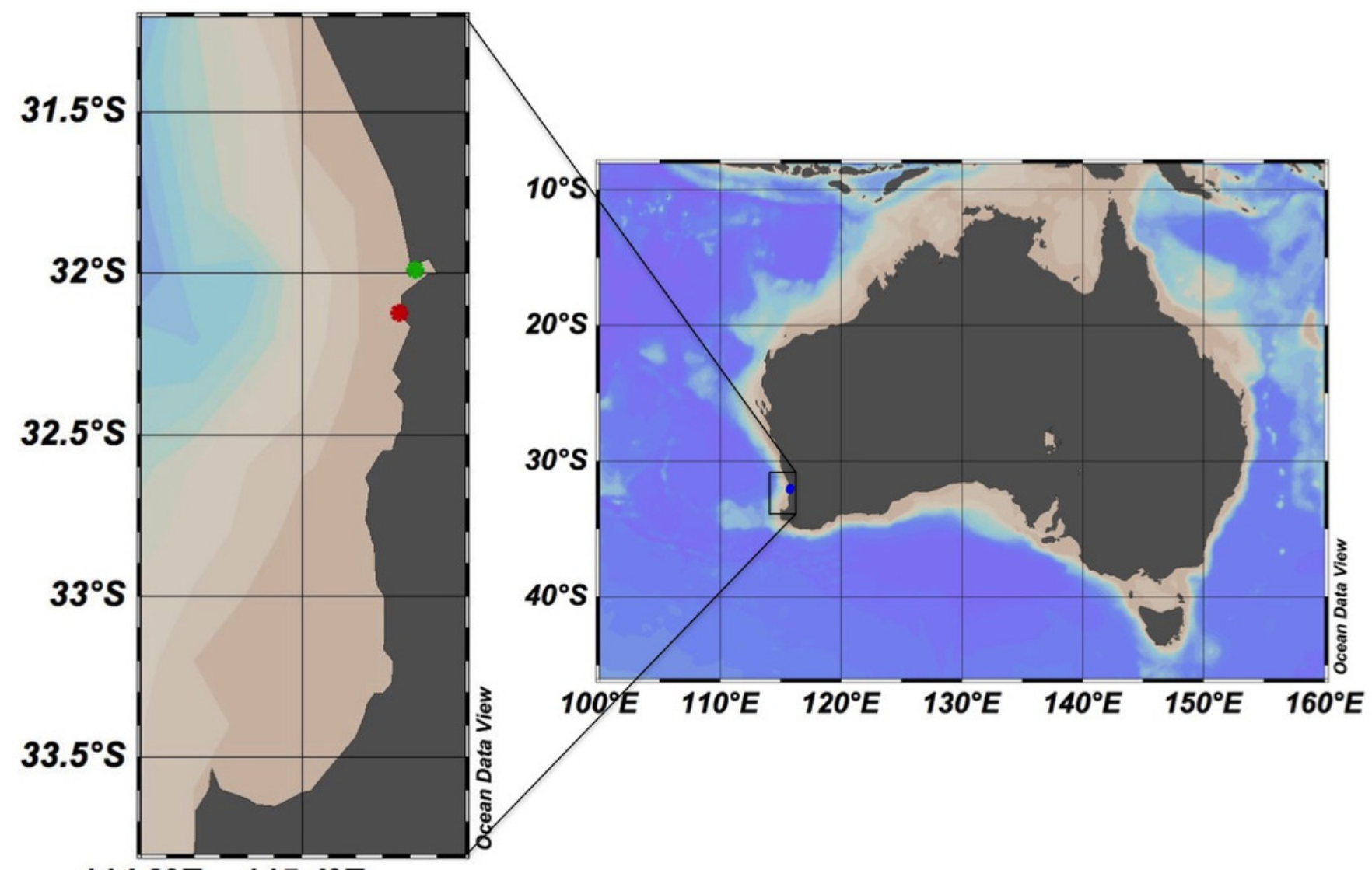

$114.8^{\circ} \mathrm{E} \quad 115.4^{\circ} \mathrm{E}$ 


\section{Figure 2}

Temporal variability in seawater temperature and salinity.

Changes in surface seawater temperature (A) and salinity (B) in Matilda Bay are shown in blue line and symbols, and in Woodman Point in red line and symbols, over time. 

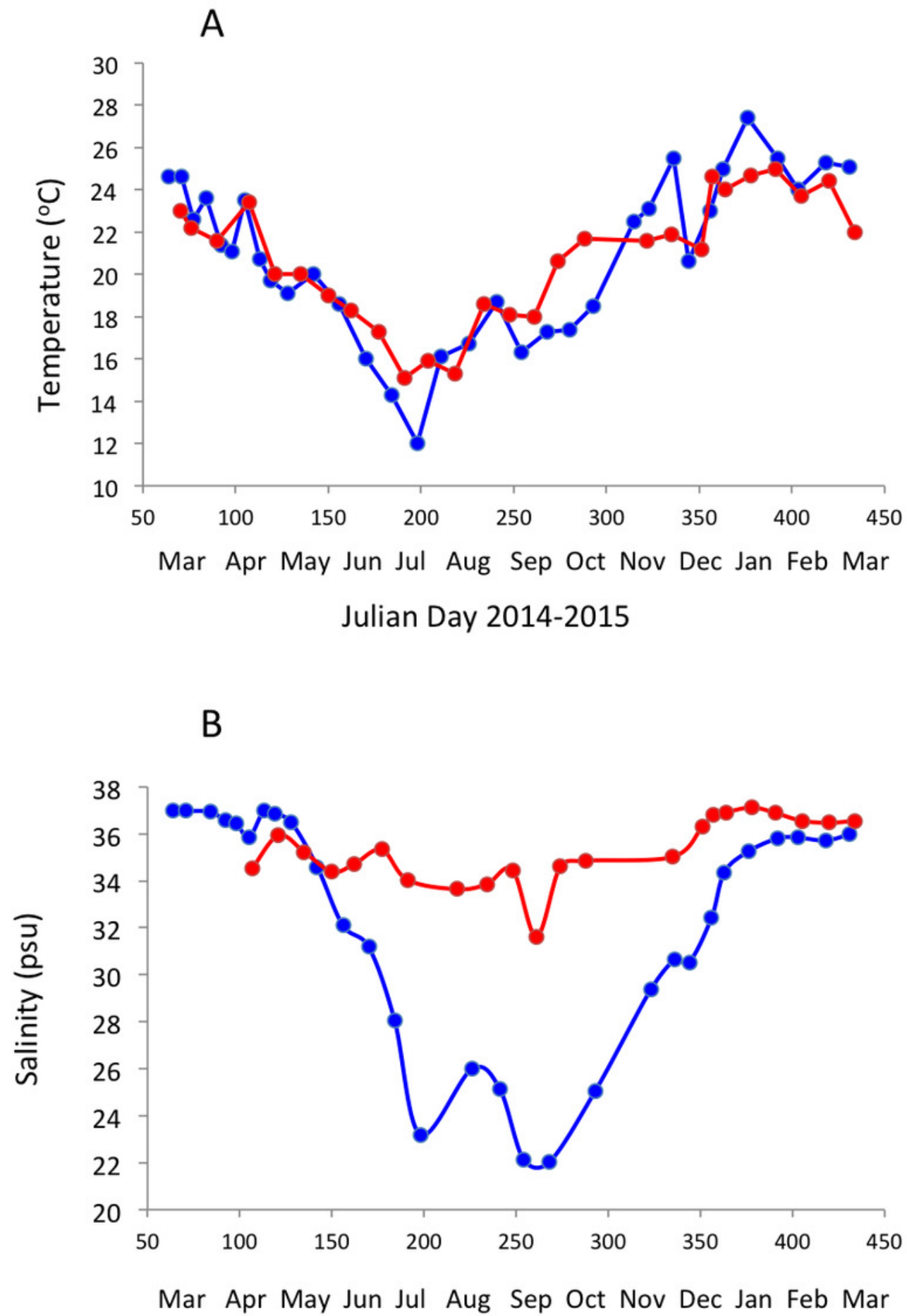

Julian Day 2014-2015 
Figure 3

Nutrients and chlorophyll a variability.

Changes in (A) nitrate, (B) ammonium, (C) phosphate and (D) chlorophyll a concentration in Matilda Bay (blue line and symbols) and Woodman Point (red line and symbols) over time.
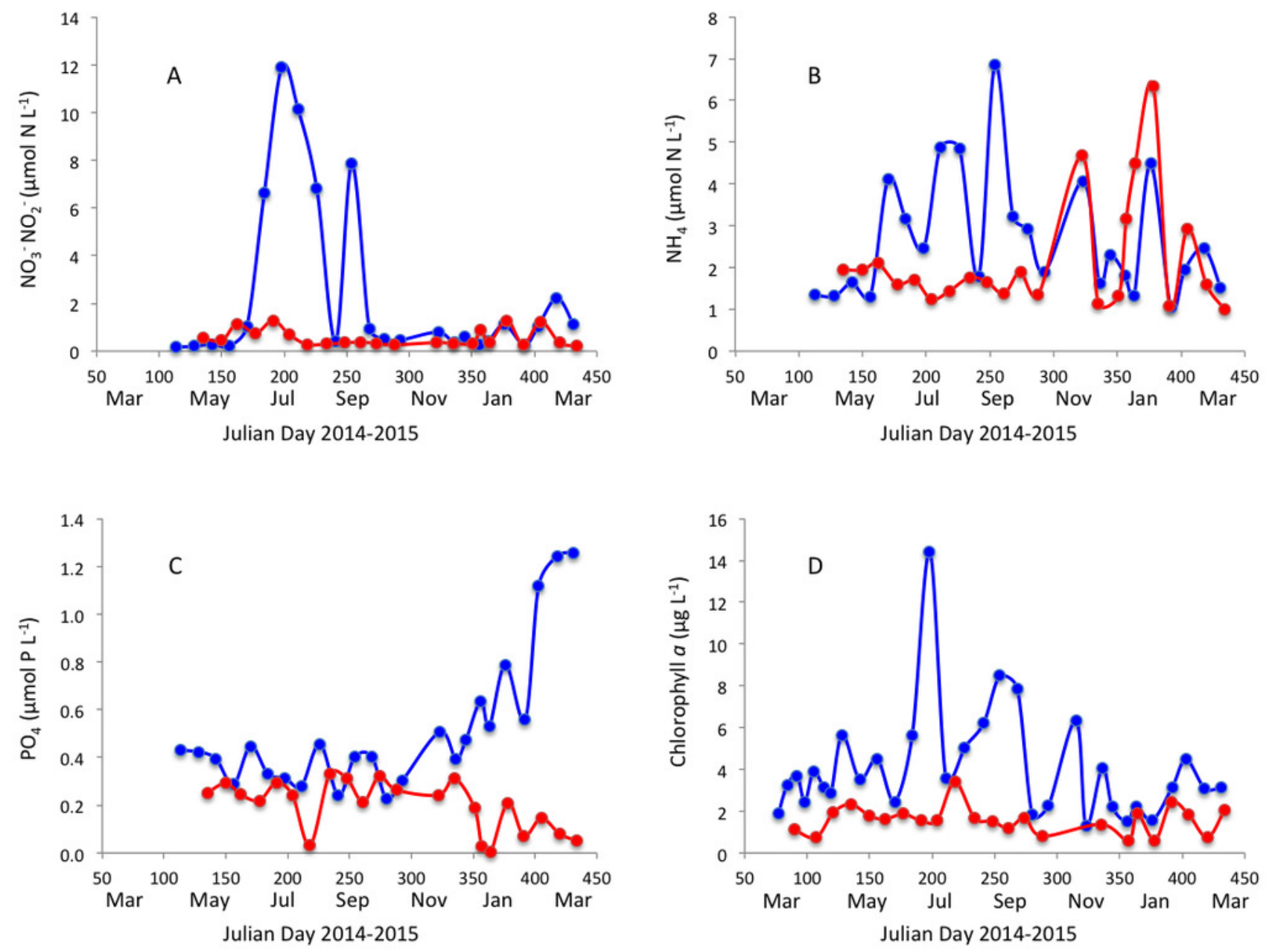


\section{Figure 4}

Planktonic metabolism.

Changes in (A) community respiration rate, (B) gross primary production, and (C) net community production in Matilda Bay (blue line and symbols) and Woodman Point (red line and symbols) over time. 

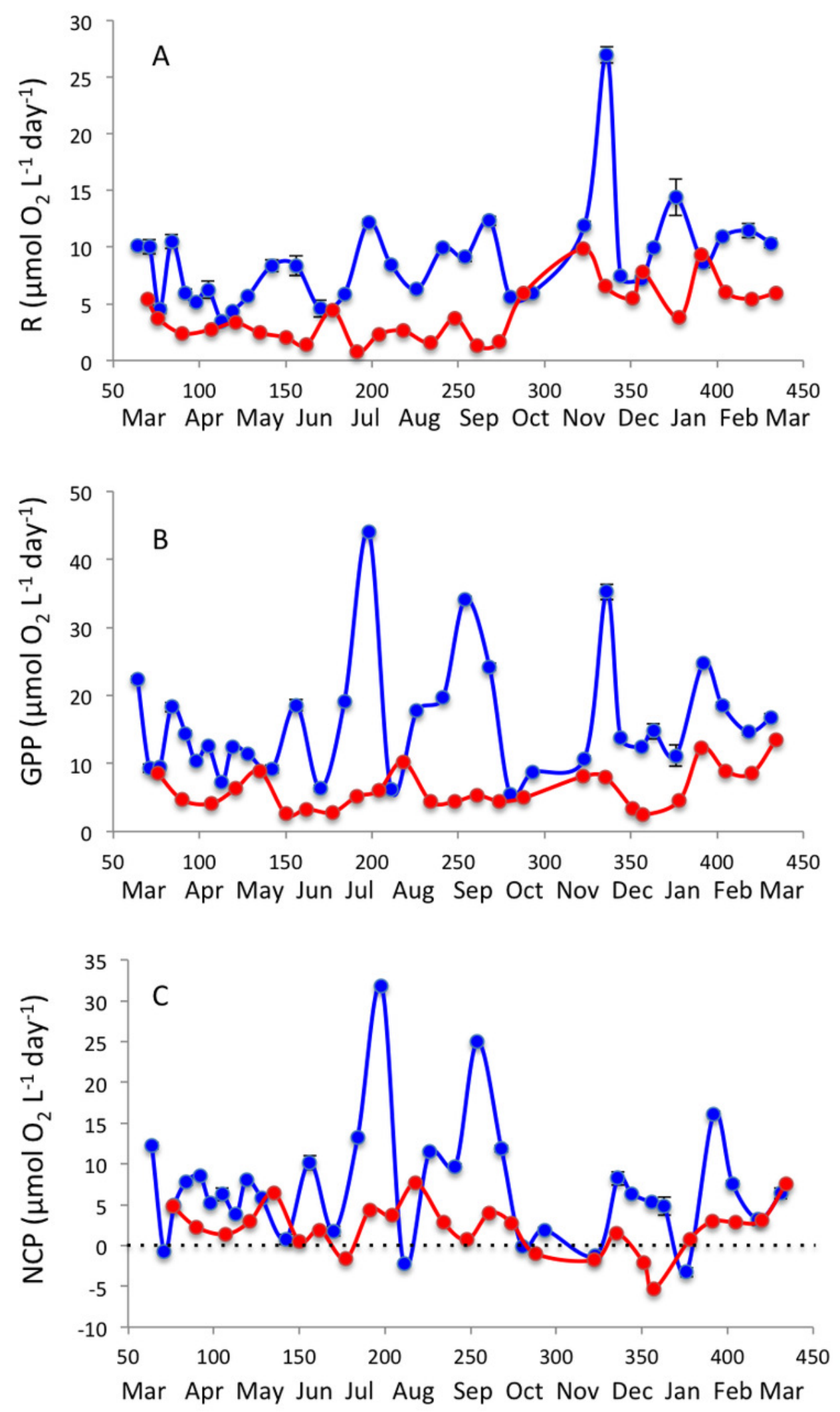

Julian Day 2014-2015 


\section{Figure 5}

The relationship between net community production and gross primary production.

The solid line shows the fitted regression equation: NCP $\left(\mathrm{mmol} \mathrm{O}_{2} \mathrm{~m}^{-3} \mathrm{~d}^{-1}\right)=-2.65+0.65( \pm$ $0.05)$ GPP $\left(\mathrm{mmol} \mathrm{O}_{2} \mathrm{~m}^{-3} \mathrm{~d}^{-1}\right)\left(\mathrm{R}^{2}=0.75, \mathrm{P}<0.0001\right)$. Blue symbols and red symbols correspond to Matilda Bay and Woodman Point, respectively.

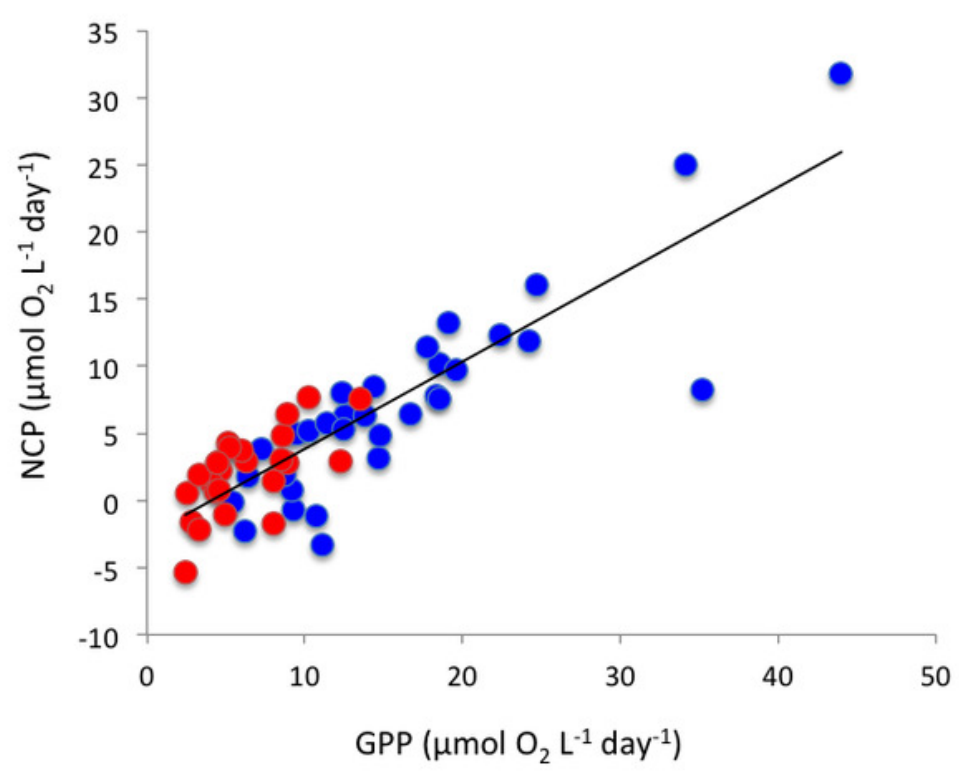




\section{Figure 6}

Plankton metabolism and phytoplankton.

The relationship between (A) net community production, (B) gross primary production and (C) community respiration and chlorophyll a concentration. The solid lines show the fitted regression equations: (A) NCP $\left(\mathrm{mmol} \mathrm{O}_{2} \mathrm{~m}^{-3} \mathrm{~d}^{-1}\right)=-1.54+2.29( \pm 0.19) \mathrm{Chl}$ a $\left(\mu \mathrm{g} \mathrm{Chl} \mathrm{a} \mathrm{L} \mathrm{L}^{-1}\right)$ $\left(\mathrm{R}^{2}=0.73, \mathrm{P}<0.0001\right) ;(\mathrm{B}) \mathrm{GPP}\left(\mathrm{mmol} \mathrm{O}_{2} \mathrm{~m}^{-3} \mathrm{~d}^{-1}\right)=2.93+3.03( \pm 0.05) \mathrm{Chl}$ a $\left(\mu \mathrm{g} \mathrm{Chl} \mathrm{a} \mathrm{L} \mathrm{L}^{-1}\right)$ $\left(\mathrm{R}^{2}=0.69, \mathrm{P}<0.0001\right)$; and $(\mathrm{C}) \mathrm{R}\left(\mathrm{mmol} \mathrm{O}_{2} \mathrm{~m}^{-3} \mathrm{~d}^{-1}\right)=4.45+0.74( \pm 0.24) \mathrm{Chl}$ a $(\mu \mathrm{g} \mathrm{Chl} \mathrm{a}$ $\left.L^{-1}\right)\left(R^{2}=0.15, P=0.0036\right)$. Blue symbols and red symbols correspond to Matilda Bay and Woodman Point, respectively. 

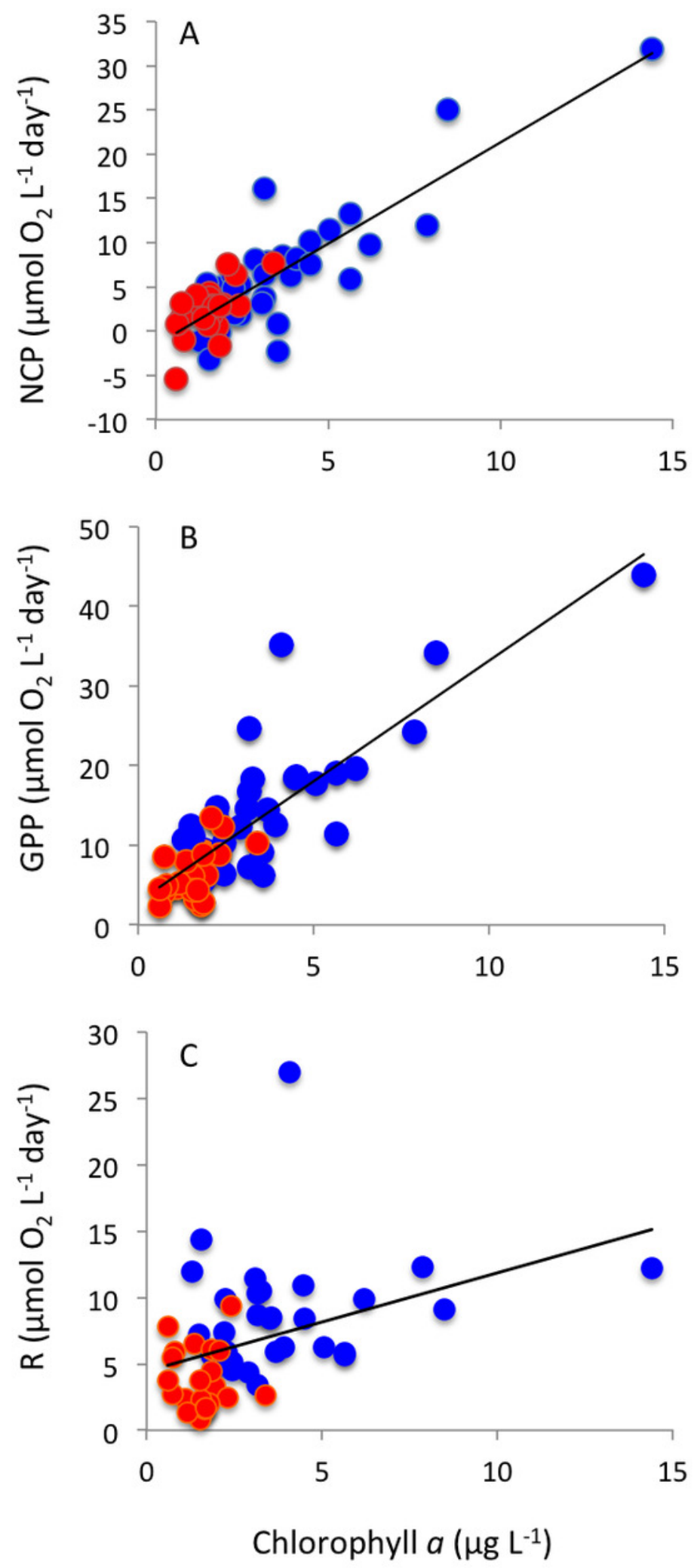


\section{Figure 7}

Thermal relationships.

Arrhenius plots showing the relationship between the natural log of $(A)$ community respiration and (B) gross primary production standardized to chlorophyll $a$, and $1 / k T$, where $k$ is the Boltzmann' s constant (8.617734 $\left.10-5 \mathrm{eV}^{\circ} \mathrm{K}^{-1}\right)$ and $\mathrm{T}$ is the sea-surface water temperature ( $\left.{ }^{\circ} \mathrm{K}\right)$ in Matilda Bay (blue symbols) and Woodman Point (red symbols). The solid lines show the fitted equations: In $R\left(\mathrm{mmol} \mathrm{O}_{2} \mathrm{mg} \mathrm{m}^{-3} \mathrm{~d}^{-1}\right)=31.87-0.76( \pm 0.21) 1 / \mathrm{kT}\left(\mathrm{R}^{2}=\right.$

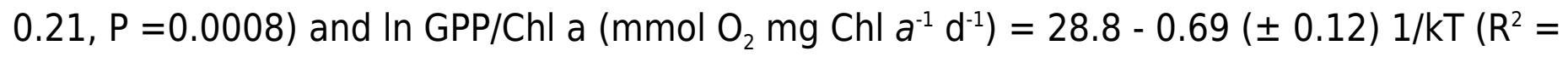
$0.41, \mathrm{P}<0.0001)$.
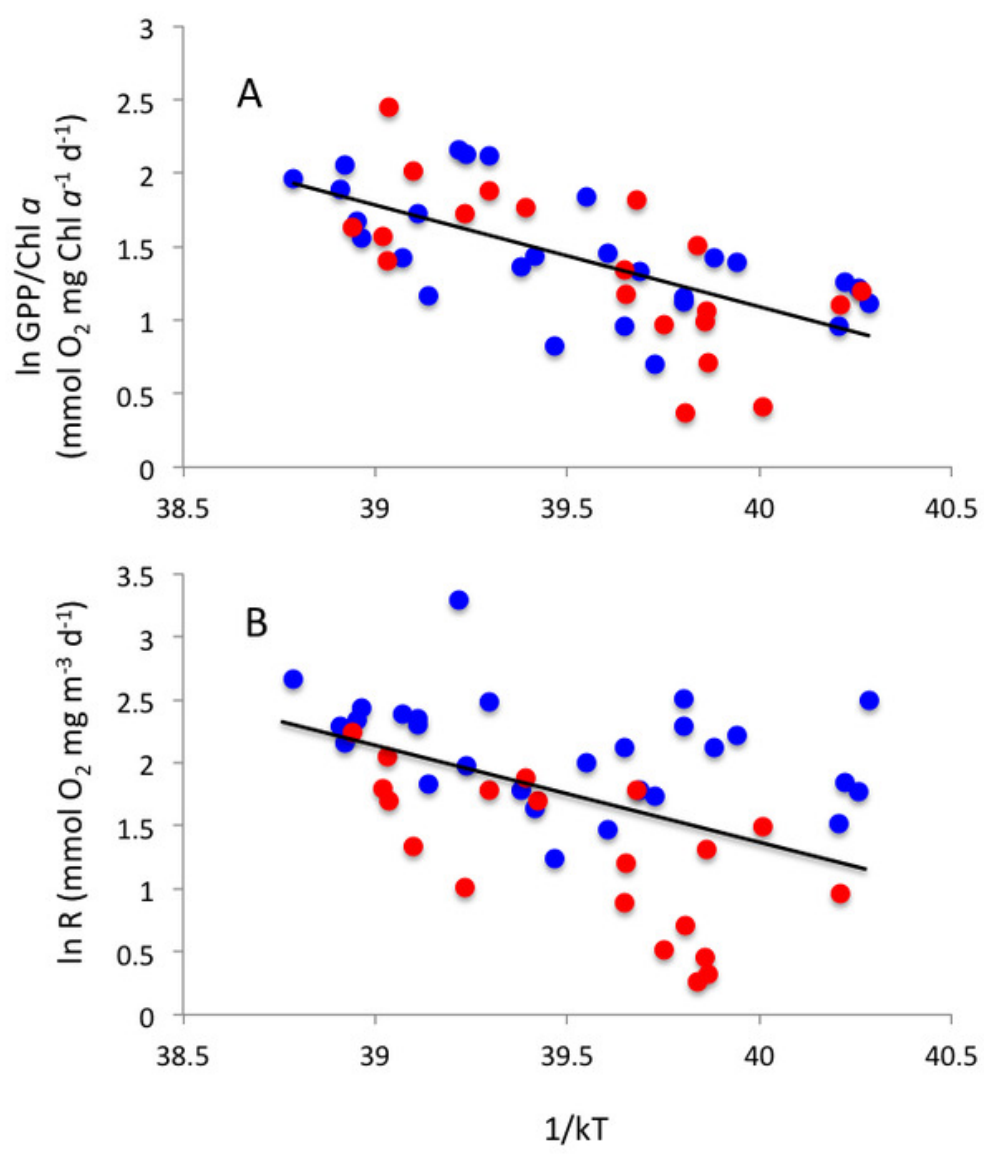